10. Griffith OW 1980 Determination of glutathione and glutathione disulfide using glutathione reductase and 2-vinylpyridine. Anal Biochem 106:207-212

11. Lohr GW, Waller HD 1974 In: Bergmeyer HU (ed) Methods of Enzymatic Analysis, Vol 2. Academic New York, pp 636-643

12. Ysebaert-Vanneste M, Vanneste WH 1980 Quantitative resolution of Cu, $\mathrm{Zn}$ and Mn-superoxide dismutase activities. Anal Biochem 107:86-95

13. Carlberg I, Altmejd B, Mannervik B 1981 Purification and immunological studies of glutathione reductase from rat liver. Biochim Biophys Acta 677:146-152

14. Paglia DE, Valentine WN 1967 Studies on the quantitative and qualitative characterization of erythrocyte glutathione peroxidase. $\mathrm{J}$ Lab Clin Med 70:158-169

15. Lowry OH, Rosebrough NJ, Farr AL, Randall RJ 195! Protein measurement with the Folin phenol reagent. J Biol Chem 193:265-275

16. Kimbell RE, Reddy K, Peirce, TH, Schwartz LW, Mustafa MG, Cross CE 1976 Oxygen toxicity: augmentation of antioxidant defense mechanisms in rat lung. Am J Physiol 230:1425-1431

17. Nishiki K, Jamieson D, Oshino N, Chance B 1976 Oxygen toxicity in the perfused rat liver and lung under hyperbaric conditions. Biochem J 160:343355

18. Bucher $\mathbf{j}$, Roberts R 1981 The development of the newborn rat lung in hyperoxia: a dose-response study of lung growth maturation, and change in antioxidant enzymes activities. Pediatr Res 15:999-1008

19. Frank $i$, Bucher JR, Roberts RJ 1978 Oxygen toxicity in neonatal and adult animals of various species. J Appl Physiol 45:699-704

20. Yam J, Frank L, Roberts RJ 1978 Oxygen toxicity: comparison of lung biochemical responses in neonatal and adult rats. Pediatr Res 12:115-119

21. Kehrer JP, Autor AP 1977 Age-dependent lipid peroxidation in neonatal rat lung tissue. Arch Biochem Biophys 181:73-81

22. Orrenius S, Ormstad K. Thor H, Jewell SA 1983 Turnover and functions of glutathione studied with isolated hepatic and renal cells. Fed Proc 42:31773188

23. Lauterburg BH, Smith CV, Hughes H, Mitchell J 1984 Biliary excretion of glutathione and glutathione disulfide in the rat: regulation and response to oxidative stress. J Clin Invest 73:124-133

24. Yam J, Frank L, Roberts RJ 1978 Age-related development of pulmonary antioxidant enzymes in the rat. Proc Soc Exp Biol Med 157:293-396

25. Kimura RE, Thulin GE, Wender D, Warshaw JB 1983 Decreased oxidative metabolism in neonatal rat lung exposed to hyperoxia. J Appl Physiol Physiol $55: 1501-1505$

26. Warshaw JB, Rosenthal MD 1972 Changes in glucose oxidation during growth of embryonic heart cells in culture. J Cell Biol 52:283-291

\title{
Modulation of Glucocorticoid Secretion by Growth Hormone
}

\author{
FRED I. CHASALOW AND SANDRA L. BLETHEN
}

The Edward Mallinckrodt Department of Pediatrics, Washington University School of Medicine, Division of Endocrinology and Metabolism, St. Louis Children's Hospital, St. Louis, Missouri 63178 and the Division of Pediatric Endocrinology, Schneider Children's Hospital of Long Island Jewish Medical Center, New Hyde Park, New York 11042

\begin{abstract}
We measured the cortisol and corticosterone responses to insulin-induced hypoglycemia in 13 growth hormone (GH)-deficient children and 30 short children without $\mathrm{GH}$ deficiency. Although there was no difference between the two groups in 1) degree of hypoglycemia attained, 2) baseline cortisol, 3) baseline coricosterone, or 4) cortisol $\mathbf{4 0} \mathrm{min}$ after insulin injection, GH-deficient children had a significantly greater corticosterone response to this stress $(3.6 \pm 0.4$ versus $1.9 \pm 0.2 \mu \mathrm{g} / \mathrm{dl})$. (All data are presented as mean \pm SEM.) In order to explore the effect of GH on corticosterone secretion, we measured cortisol and corticosterone responses to synthetic (1-24) ACTH before and after 3 days of exogenous GH (0.2 unit/ $\mathrm{kg} /$ day). In 13 GH-deficient children, GH treatment caused a significant decrease in the corticosterone response to ACTH $(2.2 \pm 0.2 \mu \mathrm{g} /$ dl before $\mathrm{GH}$ to $1.6 \pm 0.2 \mu \mathrm{g} / \mathrm{dl} ; t=$ $5.22, p<0.001$; paired $t$ test) despite the fact that there was no significant change in the cortisol response to $\mathrm{ACTH}$ $(18 \pm 2 \mu \mathrm{g} / \mathrm{dl}$ before and $16 \pm 2 \mu \mathrm{g} / \mathrm{dl}$ after $)$. When seven short children who were not GH deficient underwent a
\end{abstract}

Received February 11, 1985; accepted March 25, 1985

Requests for reprints to Fred I. Chasalow, Ph.D., Division of Pediatric Endocrinology, Schneider Children's Hospital of Long Island Jewish Medical Center, New Hyde Park, NY 11042

Supported in part by RR-36 from the General Clinical Research Centers Program of the Division of Research Resources of the NIH and by AM05105. similar 3-day course of GH, the decrease in their corticosterone response was much less although still statistically significant $(2.0 \pm 0.5$ to $1.8 \pm 0.5 \mu \mathrm{g} / \mathrm{dl}$; paired $t$ test, $p<$ $0.05)$. Again, the stimulated levels of cortisol were not affected by $\mathrm{GH}$ treatment $(19 \pm 4$ versus $18 \pm 3 \mu \mathrm{g} / \mathrm{dl})$ These results indicate that $\mathrm{GH}$ modulates the adrenal response to ACTH by suppressing corticosterone secretion without affecting cortisol secretion. In summary, this study presents two new findings. First, corticosterone levels are elevated during insulin tolerance testing in children with GH deficiency and, second, a 3-day course of GH replacement therapy causes a reduction in corticosterone serum levels after ACTH administration to more normal levels without altering the corresponding cortisol concentrations. As corticosterone is a less potent glucocorticoid, it might function as a cortisol antagonist when present in increased amounts and play a role in the poor recovery from hypoglycemia frequently observed in individuals with $\mathrm{GH}$ deficiency. (Pediatr Res 19: 823-827, 1985)

\section{Abbreviations}

GH, growth hormone

ACTH, adrenocorticotropic hormone

RIA, radioimmunoassay

SmC, somatomedin C 
Glucocorticoid secretion and function has been extensively studied in man and animal model systems. Cortisol and/or corticosterone are the main glucocorticoids secreted by the adrenal cortex in response to ACTH and they act in the liver to cause an increase in blood glucose levels. The latter process is mediated, at least in part, by binding to specific receptors, translocation to the nucleus, and susequent synthesis of specific proteins. Generally, without further consideration, rats have been used to develop models for the specific steps in the process. However, the nature of the glucocorticoids in man is very different from that in rats. Rats synthesize only corticosterone whereas humans produce both corticosterone ( $2 \mathrm{mg} /$ day) and cortisol ( 20 $\mathrm{mg} /$ day) (1). This difference may be significant because changes in glucose homeostasis and salt balance could be affected by the relative amounts of the two compounds as they do not have equal potency for both functions in bioassays (2). In humans, but not in rats, both are secreted in response to $\mathrm{ACTH}$, and both show large variation in serum concentration depending on the temporal relationship to the last episode of ACTH secretion (3). $\mathrm{ACTH}$ acts to increase glucocorticoid secretion by increasing the concentration of cyclic AMP, the second messenger (4). In turn, cyclic AMP increases conversion of cholesterol to pregnenolone (5). Regulation of the relative amounts of cortisol versus corticosterone cannot be mediated solely by ACTH and cyclic AMP because pregnenolone is a precursor of both glucocorticoids and an increase in pregnenolone synthesis ought to lead to proportional increases in both cortisol and corticosterone. Consequently, in order to change the relative proportions of these compounds, a second hormone must be involved. In this study, we show that GH-deficient children produce more corticosterone in response to insulin-induced hypoglycemia than do normal children even though there is no significant difference in cortisol secretion. The increase can be reduced after a short course of growth hormone therapy. Together these observations suggest that $\mathrm{GH}$ modulates adrenal cortex responses to $\mathrm{ACTH}$ at a step in the pathway after synthesis of pregnenolone, perhaps by regulating the amount of 17 -hydroxylase activity.

\section{MATERIALS AND METHODS}

Subjects. The responses of cortisol and corticosterone to insulin-induced hypoglycemia were studied in 13 children (three girls, 10 boys) with GH deficiency. The 12 children with idiopathic $\mathrm{GH}$ deficiency (ages $4.25-14.42 \mathrm{yr}$ ) were all prepubertal. One 11.5-yr-old boy with GH deficiency secondary to septooptic dysplasia was in midpuberty. GH deficiency was considered to be present if the child failed to raise his serum $\mathrm{GH}$ level above $10 \mathrm{ng} / \mathrm{ml}$ in response to both insulin-induced hypoglycemia and a combined arginine/L-dopa tolerance test.

Thirty children ( 20 boys, 10 girls) with normal growth rates and a $\mathrm{GH}$ response of more than $10 \mathrm{ng} / \mathrm{ml}$ to insulin-induced hypoglycemia or combined I-arginine/L-dopa stimulation served as controls. Hypoglycemia in response to an intravenous bolus of insulin $(0.1 \mathrm{unit} / \mathrm{kg})$ was considered to be adequate if serum glucose decreased by more than $50 \%$ from the fasting value.

ACTH stimulation tests were done after overnight dexamethasone suppression $\left(1 \mathrm{mg} / \mathrm{m}^{2}\right.$, po at 2200$)(7,8)$. An intravenous line was inserted between 0730 and 0830 and one or two (depending on the size of the child) baseline samples were drawn over a 15-min interval. An intravenous bolus of synthetic 1-24 ACTH $(0.25 \mathrm{mg}$, Cortrosyn) was injected at time 0 and samples for cortisol and corticosterone were taken 30 and 45 min afterward. Ten children with isolated GH deficiency (AM cortisol of greater than $20 \mu \mathrm{g} / \mathrm{dl}$ ) and two with combined $\mathrm{GH}$ and partial ACTH deficiency (maximum cortisol following insulin $<8 \mu \mathrm{g}$ / $\mathrm{dl}$, failure to increase 11-desoxycortisol after metyrapone) were studied before and after 3 days of $\mathrm{GH}$ treatment $(0.1 \mathrm{unit} / \mathrm{kg} /$ every $12 \mathrm{~h}$, intramuscular). An additional three GH-deficient children were studied $48 \mathrm{~h}$ after the start of $\mathrm{GH}$ therapy, and one $\mathrm{GH}$-deficient child was studied 24 h after the start of $\mathrm{GH}$ therapy. For these four children the initiation of GH therapy was delayed in order to explore the time course of the changes in corticosterone secretion. In all cases there was a 72 -h interval between ACTH stimulation tests, and the second ACTH test took place $12 \mathrm{~h}$ after the last $\mathrm{GH}$ injection. Seven non-GHdeficient children (four with delayed puberty, two with short stature without a delayed bone age, and one with Aarskog's syndrome) received $\mathrm{GH}$ according to the same protocol and served as controls. Cortisol and corticosterone responses to a single ACTH bolus were also studied in 11 healthy children of normal height. All subjects were euthyroid when studied.

Assays. Cortisol was measured by RIA with kits purchases from Amersham (Chicago, IL). Corticosterone was measured by RIA using a rabbit antibody prepared in our laboratory against 11 3,21 -dihydroxy-4-pregnen-3,20-dione-3-carboxymethoxyoxime: bovine serum albumin conjugate (Steraloids, Wilton, $\mathrm{NH}$ ). In this assay $0.3 \mathrm{ml}$ of serum, $2.5 \mathrm{nCi}$ of $\left[1,2,6,7-{ }^{3} \mathrm{H}\right]$ corticosterone [purchased from New England Nuclear, Boston, MA and purified by chromatography on Sephadex LH-20 (9)] and $0.6 \mathrm{ml}$ of ethyl acetate were mixed and allowed to stand at room temperature for $10 \mathrm{~min}$. An aliquot $(100 \mu \mathrm{l})$ of the ethyl acetate layer was removed and counted in a $\beta$-counter in order to estimate recovery following extraction. Two aliquots of $100 \mu 1$ each were dried under a stream of nitrogen prior to RIA. The assay mixture contained $\left[1,2,6,7-{ }^{3} \mathrm{H}\right]$ corticosterone $(10 \mathrm{nCi} /$ tube), assay buffer $\left(0.5 \% \mathrm{BSA}, 50 \mathrm{mM} \mathrm{Na}_{2} \mathrm{HPO}_{4}, 15 \mathrm{mM}\right.$ sodium azide, $\mathrm{pH} 7.4$ ), and antibody at a final dilution of 1:667 in a total volume of $300 \mu \mathrm{l}$. After an overnight incubation at $4^{\circ} \mathrm{C}, 250 \mu \mathrm{l}$ of Dextran-coated charcoal $(5 \mathrm{~g} /$ liter of Norit A, $0.5 \mathrm{~g} /$ liter Dextran $\mathrm{T}-70$, and $4.5 \mathrm{~g} /$ liter $\mathrm{NaCl}$ in assay buffer) were added to separate free from antibody-bound corticosterone. Recovery of added tracer was $86 \pm 5 \%$; intrassay variation was $8 \%$, and interassay variability was $10 \%$. The limit of detectability of corticosterone was $20 \mathrm{pg}$ which would be equivalent to $0.08 \mu \mathrm{g} /$ dl. Cortexolone, 17-hydroxyprogesterone, and androstenedione all had less than $0.1 \%$ cross-reactivity. Cortisol showed $0.2 \%$ cross-reactivity; progesterone had $2.0 \%$ cross-reactivity; desoxycorticosterone had $26 \%$ cross-reactivity.

The validity of this assay procedure for corticosterone in human serum was confirmed by chromatography on a Sephadex LH-20 column packed in a Pharmacia SR-10J column $(1 \times 40$ $\mathrm{cm})$ with the solvent system benzene-methanol (4:1). The column was eluted in an upward flow mode with a Milton-Roy mini-pump at a flow rate of $60 \mathrm{ml} / \mathrm{h}$. After addition of tracer, serum samples $(0.6 \mathrm{ml})$ were extracted with ethyl acetate $(1.2$ $\mathrm{ml}$ ) and aliquots assayed directly for corticosterone. An additional $0.3 \mathrm{ml}$ of the extract was evaporated to dryness, dissolved in $0.4 \mathrm{ml}$ of benzene-methanol( $4: 1)$, and chromatographed. Fractions of $2 \mathrm{ml}$ were collected and assayed for radiolabel $(0.5 \mathrm{ml})$ and corticosterone $(1.0 \mathrm{ml})$. When corticosterone was added to corticosterone-free serum, all of the recovered corticosterone cochromatographed with the authentic labeled steroid. Correcting for the losses inherent in the size of each fraction and aliquot, the recovery was essentially quantitative (>90\%) when the added amount of corticosterone was from 0.3 to $5 \mu \mathrm{g} / \mathrm{dl}$. When sequential samples from an ACTH stimulation test from a normal adult were treated in the same way, the major cross-reacting peak cochromatographed with authentic labeled corticosterone. Although one other minor peak (less than 10\%) was detected, there was good correspondence (within 10\%) between the corticosterone measured inthe column eluate and the corticosterone crossreacting material in the whole extract. This chromatographic procedure was repeated with samples from an ACTH test in a GH-deficient chld and with two sets of samples from the insulin tolerance test with both normal and GH-deficient children. The corticosterone values observed in the chromatographed extract and the total extract agreed $( \pm 10 \%)$ in all cases. Therefore, all of the data presented here were obtained without chromatography of the serum extract.

$\mathrm{SmC}$ was assayed by RIA (10) after acid-ethanol extraction 
(11) using antibody supplied by the National Hormone and Pituitary Program.

Statistics. Student's $t$ test and Wilcoxon's rank sum test were used to determine the statistical significance of differences between population means. The paired $t$ test was used to determine the significance of changes before and after GH. Values are reported as the mean \pm SEM (12).

\section{RESULTS}

Figure 1 shows the time course of glucocorticoid secretion for two children, one with normal GH levels and one with GH deficiency. The sequence of events after insulin administration at the start of the test is (at about 20-min intervals) 1) most intensive hypoglycemia, 2) highest glucocorticoid levels, and 3) $\mathrm{GH}$ secretion. As the GH secretory episode occurs at the same time as or shortly after the glucocorticoid secretory eisode, $\mathrm{GH}$ cannot directly stimulate or inhibit corticosterone secretion during this test.

The glucose, cortisol, and corticosterone responses to insulininduced hypoglycemia in GH-deficient and control children are summarized in Table 1. There was no significant difference between GH-deficient children and controls with respect to baseline cortisol, cortisol after insulin, glucose nadir, or baseline corticosterone. However, GH-deficient children had significantly higher corticosterone levels $40 \mathrm{~min}$ after the insulin injection. As expected, there was a significant difference in serum SmC levels between the two groups.

After 3 days of $\mathrm{GH}$ therapy, SmC levels increased from 0.31 \pm 0.09 to $1.11 \pm 0.23 \mathrm{unit} / \mathrm{ml}(p<0.02$, paired $t$ test) in the GH-deficient children. The children without $\mathrm{GH}$ deficiency also had an increase in SmC from $1.09 \pm 0.38$ to $2.81 \pm 0.53 \mathrm{unit} /$ $\mathrm{ml}(p<0.01)$.

The effect of a 3-day course of GH treatment on corticosterone secretion in response to an ACTH bolus is shown in Figure 2. For comparative purposes the responses of children of normal stature to ACTH are also shown $(C)$. Thus, the increased corticosterone response to endogenous $\mathrm{ACTH}$ (released in response to hypoglycemia) was also observed in response to exogenous $\mathrm{ACTH}$. When the two children with $\mathrm{ACTH}$ deficiency (and thus decreased cortisol and corticosterone secretion) are excluded from the calculation, the mean corticosterone response to exogenous ACTH was $2.42 \pm 0.22 \mu \mathrm{g} / \mathrm{dl}$ for $\mathrm{GH}$-deficient children prior to treatment versus $1.53 \pm 0.19 \mu \mathrm{g} / \mathrm{dl}$ for children of normal stature $(p<0.01$ by both Student's $t$ test and Wilcoxon rank sum test). In the short children that comprised our non-GH deficient group $(B)$, the corticosterone levels after ACTH administration were $2.0 \pm 0.5 \mu \mathrm{g} / \mathrm{dl}$. However, one of these children had extremely high corticosterone $(5 \mu \mathrm{g} / \mathrm{dl})$ levels in response to ACTH. This child was dysmorphic and extremely short, had a very delayed bone age, and had a severely disturbed home environment but was not $\mathrm{GH}$ deficient and did not respond to GH therapy; we could not determine the exact cause of her short stature or the cause of the high serum corticosterone levels secreted in response to $\mathrm{ACTH}$

GH treatment did not change the suppressed baseline cortisol $(<1.0 \mu \mathrm{g} / \mathrm{dl})$ and corticosterone $(<0.1 \mu \mathrm{g} / \mathrm{dl})$ levels. The cortisol level after stimulation was unaffected by GH treatment $(18 \pm 3$

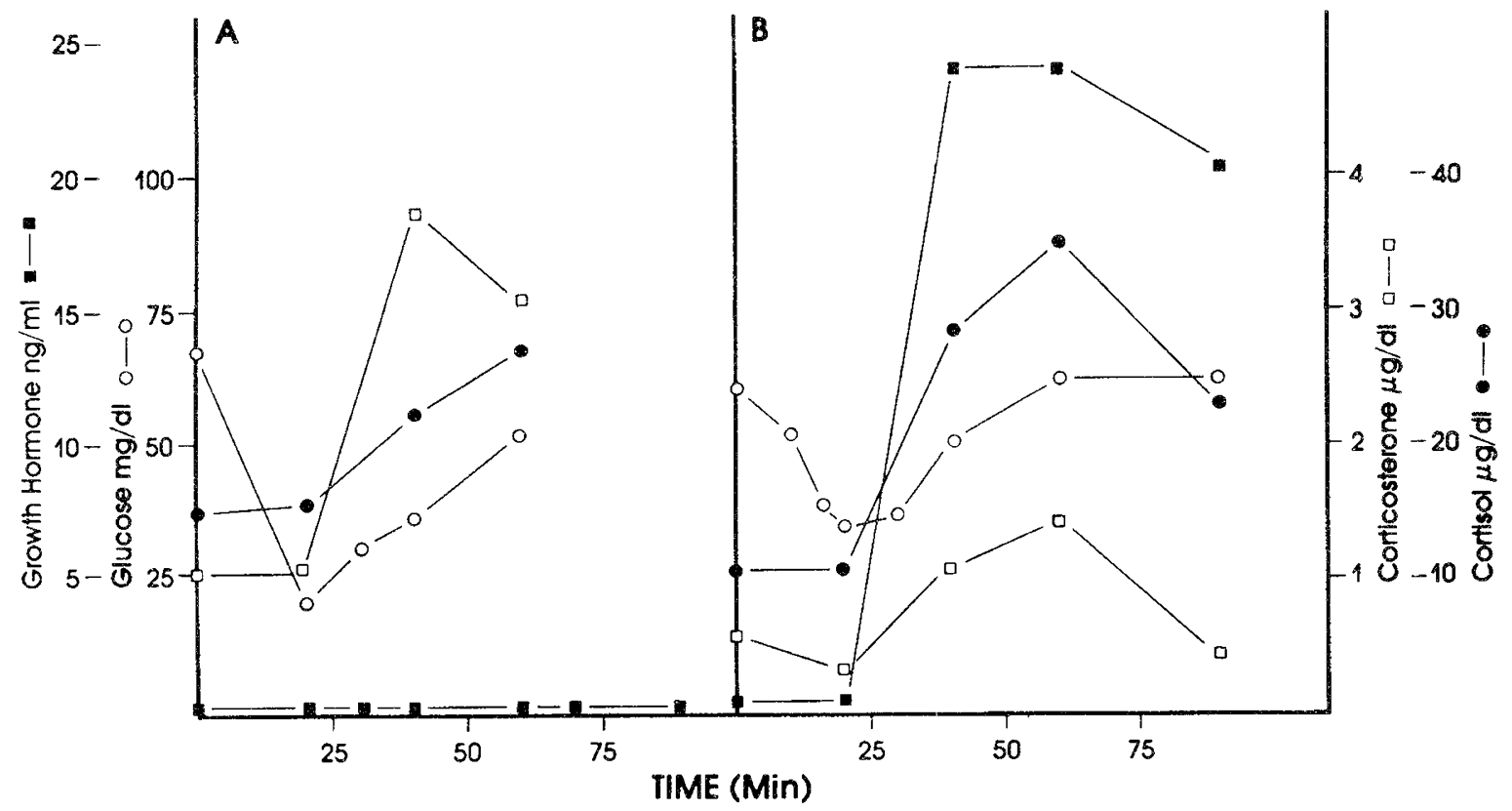

Fig. 1. Response to insulin-induced hypoglycemia in a child with GH deficiency $(A)$ and a short child without GH deficiency $(B)$. At time zero each subject received $0.1 \mathrm{unit} / \mathrm{kg}$ of regular insulin as an intravenous bolus. Serum samples were taken at the indicated times. Glucose $(\mathrm{O}-\mathrm{O})$; $\mathrm{GH}$ $(-\mathbf{a})$; cortisol $(-\square)$; corticosterone $(\square-\square)$.

Table 1. Response to insulin-induced hypoglycemia

\begin{tabular}{|c|c|c|c|c|c|c|}
\hline Patient & $\begin{array}{c}\mathrm{Sm}-\mathrm{C} \\
\text { (unit/ml) }\end{array}$ & $\begin{array}{l}\text { Glucose nadir } \\
(\mathrm{mg} / \mathrm{dl})\end{array}$ & $\begin{array}{c}\text { Cortisol (baseline) } \\
(\mu \mathrm{g} / \mathrm{dl})\end{array}$ & $\begin{array}{c}\text { Corticosterone } \\
\text { (baseline) } \\
(\mu \mathrm{g} / \mathrm{dl})\end{array}$ & $\begin{array}{l}\text { Cortisol } \\
\text { (stim)* }^{*} \\
(\mu \mathrm{g} / \mathrm{dl})\end{array}$ & $\begin{array}{c}\text { Corticosterone } \\
(\mathrm{stim}) \\
(\mu \mathrm{g} / \mathrm{dl})\end{array}$ \\
\hline Normal $(n=30)$ & $0.86 \pm 0.07 \dagger$ & $36 \pm 2$ & $23 \pm 1$ & $1.6 \pm 0.2$ & $23 \pm 1$ & $1.9 \pm 0.2$ \\
\hline GH deficient $(n=13)$ & $0.22 \pm 0.05 t$ & $31 \pm 3$ & $19 \pm 1$ & $1.7 \pm 0.3$ & $25 \pm 2$ & $3.6 \pm 0.4+$ \\
\hline
\end{tabular}

* Stimulated cortisol and corticosterone levels were measured on serum obtained forty minutes after the administration of insulin.

$\uparrow$ Values are reported as mean \pm SEM.

$\ddagger p<0.001$ compared to normal. 


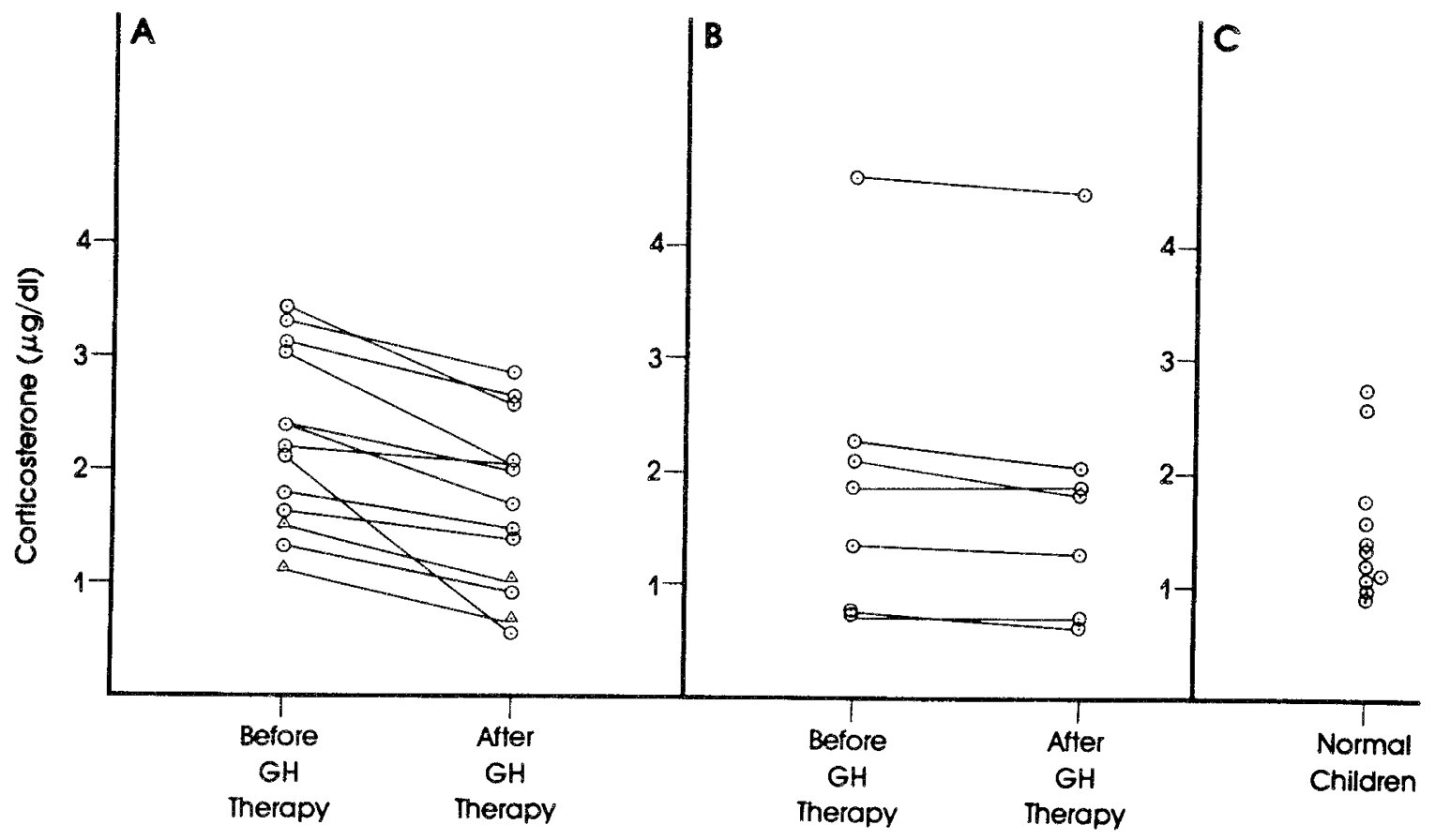

Fig. 2. Effect of GH on the corticosterone secretory response to ACTH after dexamethasone suppression. Each of the values shown is the average of the samples taken 30 and $45 \mathrm{~min}$ after administration of ACTH. $A$ shows the result in children with isolated GH deficiency $(\mathrm{O}-\mathrm{O})$ and combined $\mathrm{GH}$ and $\mathrm{ACTH}$ deficiency $(\triangle-\Delta)$. B shows the results in short children without GH deficiency. $C$ shows the corticosterone secretory response to a single injection of $\mathrm{ACTH}$ after dexamethasone suppression in 11 children of normal stature.

$\mu \mathrm{g} / \mathrm{dl}$ before and $16 \pm 2 \mu \mathrm{g} / \mathrm{dl}$ afte 3 days of $\mathrm{GH})$. In the nonGH-deficient children, GH treatment also had no significant effect on the stimulated cortisol response to ACTH $(19 \pm \mu \mathrm{g} / \mathrm{dl}$ before $\mathrm{GH}$ and $18 \pm 4 \mu \mathrm{g} / \mathrm{dl}$ after $\mathrm{GH})$.

In the children with $\mathrm{GH}$ deficiency, there was a significant $(2.2$ \pm 0.2 versus $1.6 \pm 0.2 \mu \mathrm{g} / \mathrm{dl} ; t=5.22, p<0.001$ ) decrease in the corticosterone level after ACTH stimulation after 3 days of $\mathrm{GH}$ treatment. This decrease was seen both in children with normal ACTH reserves and in the two children with evidence of ACTH deficiency. In the non-GH-deficient children, the corticosterone response to ACTH showed a statistically significant decrease $(t$ $=2.73, p<0.05$ ), but the magnitude of the decrease was much smaller than in the children with GH deficiency $(0.56 \pm 0.11$ versus $0.12 \pm 0.05 \mu \mathrm{g} / \mathrm{dl}, t=3.70, p<0.01$ ).

In the three GH-deficient children who received GH for $48 \mathrm{~h}$ prior to the second ACTH test, there was still a significant decrease in the maximal corticosterone response $(1.7 \pm 0.4$ to $1.3 \pm 0.5 \mu \mathrm{g} / \mathrm{dl}, t=10.0 p<0.01$ ), and a significant increase in $\mathrm{SmC}(0.43 \pm 0.46$ to $1.41 \pm 0.6 \mathrm{unit} / \mathrm{ml} ; t=4.51, p<0.05)$. A single child who received $\mathrm{GH}$ for $24 \mathrm{~h}$ prior to testing also showed a decrease in his corticosterone response (1.8 to $1.6 \mu \mathrm{g} /$ dl).

\section{DISCUSSION}

In this report we present two new findings. First, corticosterone secretion is elevated in response both to endogenous and exogenous ACTH in children with GH deficiency. Second, a 3-day course of GH replacement therapy causes a significant decrease in corticosterone secretion (toward the normal levels) without altering cortisol secretion. Although GH receptors are present in high concentrations in the adrenal cortex (13) and there is an accumulation of labeled $\mathrm{GH}$ in the adrenal when [125-I] GH is administered to rats (14), a specific regulatory effect of $\mathrm{GH}$ on this tissue has not been previously recognized. Thus, these experiments demonstrate that $\mathrm{GH}$ has a significant effect on steroid production in the adrenal cortex.

This study was prompted by the observation that children with GH deficiency often have poorer recovery from insulin-induced hypoglycemia than do children without GH deficiency. The poor recovery suggested a defect in a counter regulatory hormone such as a glucocorticoid. In fact, cortisol measurements during the test were frequently made to evaluate simultaneously pituitary reserves of ACTH and the response of the adrenal cortex. Because both cortisol and corticosterone are produced in relatively large amounts in humans, it seemed appropriate to measure both compounds. As shown in Table 1, although there was no statistically significant difference in the other parameters we measured, there was almost a 2-fold greater increase in corticosterone secretion in children with GH deficiency when compared to normal children. This effect could be caused either by a difference in the secretion of the pituitary trophic hormone or by a difference in the effect of the trophic hormone on the adrenal cortex itself. To distinguish these possibilities we developed a protocol for repeated ACTH administration. If the corticosterone secretion was normal after stimulation by exogenous $\mathrm{ACTH}$, then the difference must be at the pituitary level; if the corticosterone secretion was exaggerated, then the difference must be in the adrenal cortex itself.

Previously, it has been shown that when ACTH is administered on sequential days, the amount of cortisol secreted in response to the second ACTH bolus is increased. However, when the second test is delayed for at least 3 days, there is no such increase (15). In order to avoid the effect of repeated injections of ACTH on adrenal secretion, we performed the ACTH stimulation tests 3 days apart. We found a substantial decrease in corticosterone following GH treatment although there was no effect on serum cortisol levels. The magnitude of the change in corticosterone levels in GH-deficient children was three times larger than the change seen in normal children on the same protocol. Thus, GH modulates the production of individual glucocorticoids in the adrenal cortex itself. Since the difference in structure between cortisol and corticosterone is only the presence of an hydroxy group at the 17 position, GH apparently modulates glucocorticoid production by regulating the amount of 17-hydroxylase activity.

Most studies of the effect of $\mathrm{GH}$ on adrenal function have 
used the rat as a model. In intact rats $\mathrm{GH}$ treatment results in an increase in corticosterone synthesis probably due to an increase in mitochondrial cholesterol side-chain cleavage activity $(16,17)$. In hypophysectomized rats, combined replacement of $\mathrm{GH}$ and $\mathrm{ACTH}$ results in an increased trophic effect compared to that seen with ACTH alone. There is an increased activity of all of the microsomal hydroxylases, but it is difficult to separate the effects of $\mathrm{GH}$ in this system from those of ACTH itself (18). Thus, in both of these experiments with rats, corticosterone secretion increased in response to $\mathrm{GH}$ administration and this is the exact opposite of our observation in humans. However, there are two significant differences between our studies in humans and the studies with rats. First, a rat model with isolated $\mathrm{GH}$ deficiency does not exist. Thus, the first experiment evaluated pharmacological doses of $\mathrm{GH}$ and the second experiment attempted to evaluate combined deficiency of all hormones secreted by the anterior pituitary. Second, rats use only corticosterone as a glucocorticoid and do not synthesize cortisol whereas in humans, cortisol is the major glucocorticoid and corticosterone is produced in much smaller amounts. In fact since the apparent target of $\mathrm{GH}$ action in the human adrenal is the 17hydroxylase enzyme activity and since that enzyme activity is not used by the rat to produce glucocorticoids, GH cannot be acting in the rat adrenal cortex in the same manner and, consequently, the rat is not a good model for the process.

The increase in corticosterone secretion during chronic $\mathrm{GH}$ deficiency, which would be a logical consequence of our experiments, may be a factor in the hyoglycemia frequently seen in GH-deficient children. Although both cortisol and corticosterone are bound to the glucocorticoid-binding protein, the protein has a greater affinity for cortisol (19). Thus, a greater amount of corticosterone would be unbound and available to the receptor for glucocorticoids. However, corticosterone is a weaker agonist for glucocorticoid activity than is cortisol and may act as an antagonist when present in excess (20). In addition to a direct effect at the receptors for glucocorticoids in the liver, corticosterone might also serve as an antagonist in the adrenal medulla. The secretion of catecholamines is sharply decreased in children with GH deficiency (21). Rudman et al. (22) showed that although the secretion of norepinephrine was unchanged in these children, the synthesis of epinephrine was decreased $80-90 \%$. The enzyme that converts norepinephrine to epinephrine (phenolethanolamine $\mathrm{N}$-methyl transferase) requires a high concentration of a glucocorticoid for activity (23). Since corticosterone is less effective as an agonist, it might serve as a partial antagonist in the medulla and not activate this enzyme. Thus, there might be a dual mechanism for the delay in the recovery process from episodes of hypoglycemia.

\section{REFERENCES}

1. Peterson RE 1957 Plasma corticosterone and hydrocortisone levels in man. J Clin Endocrinol Metab 17:1150-1157
2. Axelrad BJ, Cates JE, Johnson BB, Luetscher JA 1954 Bioassay of mineralocorticoids: relationship of structure to physiological activity. Endocrinology 55:568-574

3. Nabors CJ, West CD, Mahajan DK, Tyler FH 1974 Radioimmunoassay of human plasma corticosterone: method, measurement of episodic secretion and adrenal suppression and stimulation. Steroids 23:363-378

4. Hayashi K, Sala G, Catt KJ, Dufau ML 1979 Regulation of steroidogenesis by adrenocorticotrophic hormone in isolated adrenal cells. $J$ Biol Chem 254:6678-6683

5. Gill GN 1979 ACTH regulation of the adrenal cortex. In: Gill GN (ed) Pharmacology of Adrenal Cortical hormones. Pergamon Press, Oxford, pp $35-36$

6. Weldon VV Gupta SK, Klingensmith G, Clarke WL, Duck SC, Haymond MW, Pagliara AS 1975 Evaluation of growth hormone release in children using arginine and L-dopa in combination. J Pediatr 87:540-544

7. Child DF, Bulock DE, Hillier VF, Anderson DC 1979 Heterogenity in adrenal steroidogenesis in normal men and women. Clin Endocrinol (Oxf) 11:38:3389

8. Granoff AB, Chasalow FI, Blethen SL 1,985 17-Hydroxyprogesterone response to ACTH in children with premature adrenarche. J Clin Endocrinol Metab 60:409-415

9. Chasalow FI 1979 Mechanism and control of rat testicular steroidogenesis. J Biol Chem 254:3000-3005

10. Furlanetto RW, Underwood LE, Van Wyk JJ, D'Ercole AJ 1977 Estimation of somatomedin-C levels in normals and patients with pituitary disease by radioimmunoassay. J Clin Invest 60:648-657

11. Daughaday WH, Mariz IK, Blethen SL 1980 Inhibition of access of bound somatomedin to membrane receptor and immunobinding sites: a comparison of radioreceptor and radioimmunoassay of somatomedin in native and acid-ethanol-extracted serum. J Clin Endocrinol Metab 15: 781-788

12. Swinscow TDV 1981 Statistics at Square One. British Medical Association, London

13. Posner BI, Kelly PA, Shiu PC, Friesen HG 1974 Studies of insulin, growth hormone and prolactin binding: tissue distribution, species variation and characterization. Endocrinology 95:521-531

14. DeKrester DM, Catt KJ, Burger HG, Smith GC 1969 Radioautographic studies on the localization of ${ }^{125}$ l-labeled human luteinizing and growth hormone in immature male rats. J Endocrinol 43:105-111

15. Kolanowski J, Pizarro MA, Crabbe 1975 Potentiation of adrenocortical response upon intermittent stimulation with corticotropin in normal subjects J Clin Endocrinol Metab 41:453-465

16. Coyne MD 1984 Effect of growth hormone and corticotropin on steroidogenesis in cultured rat adrenocortical cells. Horm Res 19:185-190

17. Kramer RE, Greiner JW, Colby HD 1977 Site of action of growth hormone on adrenocortical steroidogenesis in rats. Endocrinology 101:297-303

18. Murakami N, Takahashi K 1983 Enhancement of corticosterone release by repeated injections of $\mathrm{ACTH}$ in the dexamethasone pre-treated rat. Acta Endocrinol 102:583-588

19 Daughaday WH 1958 Binding of corticosteroids by plasma proteins III. The binding of corticosteroid and related hormones by human plasma and plasma protein fractions as measured by equilibrium dialysis. J Clin Invest 37:511 518

20. Brorson 11968 Concentration of corticosterone and cortisol in periphera plasma of patients with adrenocortical hyperplasia and normal subjects. Acta Endocrinol 58:445-462

21. Voorhess ML, MacGillivray MH 1984 Low plasma norepinephrine responses to acute hypoglycemia in children with isolated growth hormone deficiency. J Clin Endocrinol Metab 59:790-793

22. Rudman D, Moffitt SD, Fernhoff PM, Blackston RD, Faraj BA 1981 Epinephrine deficiency in hypocorticotropic hypopituitary children. J Clin Endocrinol Metab 53:722-729

23. Wurtman RJ, Axelrod J 1966 Control of enzymatic synthesis of adrenaline in the adrenal medulla by adrenal cortical steroids. J Biol Chem 241:23012305 